\title{
Influence of Crop Establishment Methods, Weed and Nutrient Management Practices on Growth and Yield of Direct Seeded Rice (Oryza sativa)
}

\author{
V. Sridevi ${ }^{*}$, S. Jeyaraman ${ }^{2}$, S. Ramasamy ${ }^{2}$ and C. Chinnusamy ${ }^{2}$ \\ ${ }^{1}$ Pandit Jawaharlal Nehru College of Agriculture and Research Institute, \\ Pondicherry University, Karaikal, Puducherry U.T. - 609 603, India \\ ${ }^{2}$ Tamil Nadu Agricultural University, Coimbatore, Tamil Nadu-641 003, India \\ *Corresponding author
}

\begin{abstract}
Keywords
Direct seeded rice, Growth attributes, Harvest index, Yield attributes, Yield.

Article Info

Accepted:

26 September 2017

Available Online:

10 November 2017 methods and weed management practices ( $\mathrm{M}_{1}$ : Direct planting system (DPS), $\mathrm{M}_{2}$ : DPS + EPOE of almix @ $4 \mathrm{~g}$ a.i. ha ${ }^{-1}, \mathrm{M}_{3}$ : DPS without thinning and hand weeding in the intersect + EPOE of almix @ $4 \mathrm{~g}$ a.i ha ${ }^{-1}, \mathrm{M}_{4}$ : drum seeding) were assigned to main plots and nutrient management practices $\left(S_{1}\right.$ : Absolute control, $S_{2}$ : Recommended fertilizer dose of 150:50:50 kg NPK ha ${ }^{-1}+12.5$ t FYM ha $^{-1}, \mathrm{~S}_{3}: \mathrm{S}_{2}+$ Pseudomonas fluorescens (Seed treatment @ $10 \mathrm{~g} \mathrm{~kg}^{-1}$ and soil application@ $2.5 \mathrm{~kg} \mathrm{ha}^{-1}$ and 0.2 per cent foliar spray), $\mathrm{S}_{4}$ : $\mathrm{S}_{2}+$ Azophosmet (Seed treatment @ $2 \mathrm{~g} \mathrm{~kg}^{-1}$ and soil application @ $2 \mathrm{~kg} \mathrm{ha}^{-1}$ ) $+0.1 \mathrm{per}$ cent Pink pigmented facultative methylotroph (PPFM) foliar spray) were allocated to sub plots. The results showed that the highest growth, yield attributes, grain yield and harvest index were obtained by direct planting system (DPS) + EPOE of almix at $4 \mathrm{~g}$ a.i. $\mathrm{ha}^{-1}$. The drum seeding produced the highest straw yield. The combined application of recommended dose of fertilizer (150:50:50 kg NPK ha ${ }^{-1}$ ) along with $12.5 \mathrm{t} \mathrm{ha}^{-1}$ FYM and biofertilizers viz., Azophosmet as soil and seed treatment and 0.1 per cent pink pigmented facultative methylotroph (PPFM) as foliar spray at active tillering, panicle initiation and 50 per cent flowering stage registered higher growth, yield attributes, grain and straw yield and harvest index.
\end{abstract}

\section{A B S T R A C T}

Field experiments were conducted in clay loam soil of Tamil Nadu Agricultural University, Coimbatore during rabi, 2009-10 and 2010-11 to identify the suitable crop establishment methods, weed and nutrient management practices in direct seeded rice. The field experiments were laid out in split plot design replicated thrice. Crop establishment

\section{Introduction}

Direct seeding on puddled soil either through broadcasting or row seeding by drum seeder is gaining popularity due to low labour requirement, shorter crop duration, efficient water use and provide comparable grain yield as that of transplanted rice (Gangwar et al., 2008). However, it has many limitations such as uneven crop stand, difficulty in thinning and gap filling and inefficient manual weeding. These problems can be overcome by the Direct Planting System (DPS), in which desired plant density $(25 \mathrm{~cm} \times 25 \mathrm{~cm})$ like SRI is maintained by thinning the direct seeded rice with manual and mechanical means (rotary weeder). There was 60 per cent saving of labour during crop establishment stages (sowing, transplanting and weeding) as compared to transplanted rice (Ramasamy et 
al., 2006). A weed-free period for the first 3045 days after sowing (DAS) is required to avoid any loss in grain yield (Singh and Singh, 2010). Herbicides alone or in combination with mechanical and hand weeding are effective in controlling weeds in rice (Mirza et al., 2009). Soil fertility maintenance is essential for sustainable rice production. Due to escalation of fertilizer prices and associated environment problem of inorganic cultivation, it is necessitated to exploit the available resources of nutrients under the theme of integrated nutrient management. Under this approach, the best available option lies in the complimentary use of biofertilizers, organic manures in suitable combination of inorganic fertilizer (Jayasankar and Thyagarajan, 2010). With this background, the experiments were carried out to elucidate the growth, yield attributes and productivity of direct seeded rice under different crop establishment methods, weed and nutrient management practices.

\section{Materials and Methods}

The field experiments were conducted to evaluate the effect of crop establishment methods, weed and nutrient management practices on the growth, yield attributes and yield of lowland direct seeded rice during rabi, 2009-10 and 2010-11 at the wetlands of Tamil Nadu Agricultural University, Coimbatore which is situated in North western agro-climatic zone of Tamil Nadu at $11^{\circ} \mathrm{N}$ and $77^{\circ} \mathrm{E}$ with an altitude of $426.7 \mathrm{~m}$ above mean sea level.

Soil of the experimental fields was clay loam in texture classified taxonomically as Vertic Ustochrept, low in available nitrogen (197.3$\left.214.2 \mathrm{~kg} \mathrm{ha}{ }^{-1}\right)$, medium in available phosphorus (11.8-12.5 $\mathrm{kg} \mathrm{ha}^{-1}$ ) and high in available potassium (451.8-509.0 kg ha-1). The medium duration rice variety ' $\mathrm{CO}(\mathrm{R}) 50$ ' was used as test variety.
The field experiments were laid out in split plot design replicated thrice. Crop establishment methods and weed management practices $\left(\mathrm{M}_{1}\right.$ : Direct planting system (DPS), $\mathrm{M}_{2}$ : DPS + EPOE of almix @ $4 \mathrm{~g}$ a.i. ha ${ }^{-1}$, $\mathrm{M}_{3}$ : DPS without thinning and hand weeding in the intersect + EPOE of almix @ $4 \mathrm{~g}$ a.i ha ${ }^{1}, \mathrm{M}_{4}$ : drum seeding) were assigned to main plots and nutrient management practices $\left(S_{1}\right.$ : Absolute control, $\mathrm{S}_{2}$ : Recommended dose of 150:50:50 kg NPK ha ${ }^{-1}+12.5$ t FYM ha $^{-1}, \mathrm{~S}_{3}$ : $\mathrm{S}_{2}+$ Pseudomonas fluorescens (Seed treatment@10 g kg-1 and soil application@ $2.5 \mathrm{~kg} \mathrm{ha}^{-1}$ and 0.2 per cent foliar spray), $\mathrm{S}_{4}$ : $\mathrm{S}_{2}+$ Azophosmet (Seed treatment @ $2 \mathrm{~g} \mathrm{~kg}^{-1}$ and soil application @ $2 \mathrm{~kg} \mathrm{ha}^{-1}$ ) +0.1 per cent Pink pigmented facultative methylotroph (PPFM) foliar spray) were allocated to sub plots.

The field was puddled and perfectly levelled and adequate drainage facility was provided. For direct planting system (DPS), seed rate of $30 \mathrm{~kg} \mathrm{ha}^{-1}$ was adopted. The sprouted seeds were uniformly broadcasted in crisscross direction. Rotary weeder was operated on eighth day after sowing to thin the plants in the row of operation (to the width of the weeder) and the same process was repeated on the crisscross direction at $25 \mathrm{~cm}$ apart which results in the formation of an intersect (equal to $12 \mathrm{~cm} \mathrm{x} 12 \mathrm{~cm}$ or more) progressively with rice plants. Second rotary weeding was done on $16^{\text {th }}$ DAS as that of the first rotary weeding. After second rotary weeding, the plants in the intersect were thinned out to one and the weeds were removed manually as per the treatment schedule, so that the field looks like SRI field $(25 \mathrm{~cm} \times 25 \mathrm{~cm})$. Rotary weeding was done two more times on 30 and $45^{\text {th }}$ DAS. Early post emergence herbicide Almix was sprayed with flat fan nozzle @ $4 \mathrm{~g}$ a.i. ha ${ }^{-1}$ after the second rotary weeding $\left(16^{\text {th }}\right.$ DAS $)$ as per the treatment schedule. For drum seeding, manually operated rice drum seeder 
developed by Tamil Nadu Agricultural University, Coimbatore was used for sowing the seeds. The seeder has two wheels at both the ends. It drops the seeds at $20 \mathrm{~cm}$ apart in continuous row. At a time, eight rows of rice seeds are sown. A seed rate of $60 \mathrm{~kg} \mathrm{ha}^{-1}$ was adopted. Rotary weeding thrice was done along the rows starting from $16^{\text {th }}$ DAS at 15 days interval in the drum seeded plots.

Before sowing, the field was drained to keep it under saturated condition to facilitate easy sowing and uniform establishment of seedlings. A thin film of water was maintained at the time of sowing. For the next 8-15 days, irrigation and drainage of water were alternated to facilitate aeration and adequate moisture for germination of seeds and establishments of seedlings. Thereafter, the plots were irrigated to $2 \mathrm{~cm}$ depth uniformly in all the treatments after the appearance of hair line cracks, up to panicle initiation stage. After panicle initiation, the plots were irrigated to $5 \mathrm{~cm}$ depth on disappearance of ponded water. Irrigation was stopped 15 days prior to harvest.

Farm yard manure was applied @ $12.5 \mathrm{t} \mathrm{ha}^{-1}$ uniformly as per the treatment schedule, incorporated and then leveled. Recommended dose of fertilizer (150:50:50 $\mathrm{kg} \mathrm{NPK} \mathrm{ha}^{-1}$ ) for the medium duration rice variety was followed as per the treatments. Nitrogen was applied in four splits viz., $40 \mathrm{~kg} \mathrm{ha}^{-1}$ each at basal, active tillering and panicle initiation stage and $30 \mathrm{~kg} \mathrm{ha}^{-1}$ at flowering stage. The entire dose of phosphorus was applied as basal. Potassium was applied in four splits viz., 25 per cent each at basal, active tillering, panicle initiation and flowering stages. Based on the treatment schedule, the pre-germinated seeds were treated with Azophosmet @ 2 g kg${ }^{1}$ (or) Pseudomonas fluorescens @ $10 \mathrm{~g} \mathrm{~kg}^{-1}$. The biofertilizers Azophosmet @ $2 \mathrm{~kg} \mathrm{ha}^{-1}$ (or) Pseudomonas fluorescens @ $2.5 \mathrm{~kg} \mathrm{ha}^{-1}$ were mixed with well decomposed FYM for uniform application throughout the plots and applied as basal. 0.1 per cent Pink Pigmented Facultative Methylotroph (PPFM) or 0.2 per cent Pseudomonas fluorescens was sprayed at active tillering, panicle initiation and at 50 per cent flowering stages.

In the net plot area, five sample hills (plants) were selected randomly and tagged for recording biometric observations. The biometric observations were recorded at tillering, panicle initiation, flowering and harvesting stages of the crop. The plant height of the tagged plants was measured from the ground level to the tip of the top most fully opened leaf or flag leaf. Tiller density $\mathrm{m}^{-2}$ was calculated by multiplying average total number of tillers hill ${ }^{-1}$ with plant population $\mathrm{m}^{-2}$. For estimating dry weight, five plants were randomly selected from sampling area. The entire hill along with root intact by soil was scooped. The samples were dried in shade and again oven dried at $60 \pm 2{ }^{\circ} \mathrm{C}$ till a constant weight was obtained. These were weighed using an electronic top pan balance. The number of days taken for emergence of 50 per cent panicles (emergence of panicles in 50 per cent of population) was recorded in individual plots based on visual assessment.

The crop was harvested when most of the plants turned yellow and attained physiological maturity. The plants from the net plot area were harvested, threshed and winnowed. Grain and straw from each net plot were sun dried, weighed and expressed in $\mathrm{t} \mathrm{ha}^{-1}$. The grain yield was adjusted to 14 per cent moisture content. Harvest index is the ratio of grain yield to biological yield. The leaf area index at different growth stages, yield and yield attributes at the time of harvest were recorded as per the procedure suggested by Yoshida et al., 1976. Data on various parameters were subjected to an analysis of variance (F-test) as per the methods suggested by Gomez and Gomez 
(2010). Significant differences $(P=0.05)$ between treatments were determined using critical difference.

\section{Results and Discussion}

\section{Growth attributes}

In general, the plant height, dry matter production was found to increase with the age of the crop. While, tiller production starts slowly in the beginning, increases steadily and attains to its peak during panicle initiation stage and then started to decline as the age of the crop advances. The decrease in tiller number on aging resulted from death of the late forming tillers due to their incompetency for light and nutrients (Barik et al., 2006). The growth attributes viz., plant height (Table 1 ), number of tillers $\mathrm{m}^{-2}$ (Table 2), dry matter production (Table 3), leaf area index (Table 4) at different growth stages and days to 50 per cent flowering (Table 4) were significantly influenced by the treatments under study during both the years.

Taller plants were observed consistently at all the growth stages with DPS + EPOE of almix @ 4 g a.i. ha ${ }^{-1}$ which might be due to lesser intra-hill competition and better weed control with favourable soil environment. This result is in accordance with the findings of Shrirame et al., (2000). Whereas, more number of tillers $\mathrm{m}^{-2}$, dry matter production and leaf area index were produced by DPS without thinning and hand weeding in the intersect + EPOE of almix @ $4 \mathrm{~g}$ a.i. ha ${ }^{-1}$ at active tillering stage due to mutual competition by already existing tillers and increased tiller mortality due to weed infestation. This result is in conformity with the findings of Janarthanan (2008). DPS and DPS + EPOE of almix@4 g a.i. ha ${ }^{-1}$ at later stages recorded more number of tillers $\mathrm{m}^{-2}$, dry matter and leaf area index due to effective utilization of the available resources such as space, foraging area for root system, light utilization etc. This result corroborates the findings of Baskar (2009). More competition among the plants under drum seeding stimulated earlier flowering. This finding was in conformity with the result of Rao and Raju (1987).

Manuring favoured the rice growth irrespective of the crop establishment methods and weed management practices. The growth attributes viz., plant height, number of tillers $\mathrm{m}^{-2}$, dry matter production, leaf area index increased with increase in fertility and attained its maximum with combined application of RDF + FYM + Azophosmet + PPFM could be attributed to greater root development, photosynthetic activity, increased availability of nutrients throughout the crop growth, higher nutrient uptake and stimulatory effect of the enhanced microbial population. This result corroborates with the findings of Virdia and Mehta (2010). Nutrient application added few more days due to addition of new tillers than absolute control and hence extended the growth period. Among the manured plots, combined application of RDF + FYM + Azophosmet + PPFM tends to flower earlier because of the stimulatory effect of biofertilizers. This result is in conformity with the findings of Viera and Alvarez (2006).

\section{Yield attributes}

Crop establishment methods, weed management and nutrient management practices had significant influence on all the yield attributes except test weight during both the years (Table 5). Direct planting system (DPS) + EPOE of almix @ 4 g a.i. ha ${ }^{-1}$ during both the years was found to be superior in registering the yield attributes viz., number of panicles $\mathrm{m}^{-2}$, panicle weight, number of grains panicle ${ }^{-1}$ and grain filling percentage. However, it was comparable with direct planting system. 
Int.J.Curr.Microbiol.App.Sci (2017) 6(11): 3725-3737

Table.1 Effect of establishment, weed and nutrient management practices on plant height $(\mathrm{cm})$ at different growth stages of rice

\begin{tabular}{|c|c|c|c|c|c|c|c|c|}
\hline \multirow{2}{*}{ Treatments } & \multicolumn{2}{|c|}{ Active tillering } & \multicolumn{2}{|c|}{ Panicle initiation } & \multicolumn{2}{|c|}{ Flowering } & \multicolumn{2}{|c|}{ Harvesting } \\
\hline & $2009-10$ & $2010-11$ & $2009-10$ & $2010-11$ & 2009-10 & 2010-11 & $2009-10$ & 2010-11 \\
\hline \multicolumn{9}{|c|}{ Crop establishment and weed management methods } \\
\hline $\mathrm{M}_{1}: \mathrm{DPS}$ & 69.1 & 67.1 & 83.6 & 86.4 & 110.5 & 114.5 & 112.8 & 118.6 \\
\hline $\mathrm{M}_{2}: \mathrm{DPS}+\mathrm{Almix}$ & 71.1 & 69.2 & 86.2 & 91.1 & 115.1 & 118.4 & 119.3 & 121.0 \\
\hline $\begin{array}{l}\mathrm{M}_{3} \text { :DPS without thinning and hand } \\
\text { weeding in the intersect + Almix }\end{array}$ & 65.9 & 65.9 & 80.7 & 83.6 & 107.5 & 109.8 & 110.4 & 112.5 \\
\hline $\mathrm{M}_{4}$ :Drum seeding & 63.4 & 60.7 & 76.9 & 79.0 & 106.7 & 103.5 & 108.0 & 107.5 \\
\hline SEm \pm & 1.8 & 1.9 & 2.0 & 2.2 & 2.1 & 2.5 & 2.9 & 1.5 \\
\hline $\mathrm{CD}(\mathrm{P}=0.05)$ & 4.4 & 4.8 & 5.0 & 5.4 & 5.3 & 6.0 & 7.1 & 3.7 \\
\hline \multicolumn{9}{|l|}{ Nutrient management practices } \\
\hline $\mathrm{S}_{1}$ :Absolute control & 56.3 & 54.2 & 68.1 & 72.2 & 94.0 & 93.0 & 96.2 & 95.8 \\
\hline $\mathrm{S}_{2}: \mathrm{RDF}+\mathrm{FYM}$ & 66.8 & 65.7 & 81.1 & 83.7 & 107.8 & 111.7 & 111.5 & 116.5 \\
\hline $\mathrm{S}_{3}: \mathrm{S}_{2}+$ Pseudomonas & 71.9 & 70.4 & 87.8 & 90.4 & 117.7 & 120.0 & 120.5 & 122.6 \\
\hline $\mathrm{S}_{4}: \mathrm{S}_{2}+$ Azophosmet $+\mathrm{PPFM}$ & 74.5 & 72.6 & 90.3 & 93.8 & 120.2 & 121.7 & 122.4 & 124.6 \\
\hline $\mathrm{SEm} \pm$ & 1.4 & 1.4 & 1.8 & 1.7 & 1.7 & 1.6 & 1.7 & 1.3 \\
\hline $\mathrm{CD}(\mathrm{P}=0.05)$ & 3.0 & 2.8 & 3.6 & 3.6 & 3.6 & 3.2 & 3.4 & 2.7 \\
\hline \multicolumn{9}{|l|}{ Interaction (MxS) } \\
\hline $\mathrm{SEm} \pm$ & 3.1 & 3.1 & 3.7 & 3.7 & 3.7 & 3.7 & 4.1 & 2.7 \\
\hline $\mathrm{CD}(\mathrm{P}=0.05)$ & 6.7 & 6.8 & 8.0 & 8.2 & 8.1 & 8.2 & 9.3 & 5.9 \\
\hline
\end{tabular}


Int.J.Curr.Microbiol.App.Sci (2017) 6(11): 3725-3737

Table.2 Effect of establishment, weed and nutrient management practices on number of tillers $\mathrm{m}^{-2}$ at different growth stages of rice

\begin{tabular}{|c|c|c|c|c|c|c|c|c|}
\hline \multirow{2}{*}{ Treatments } & \multicolumn{2}{|c|}{ Active tillering } & \multicolumn{2}{|c|}{ Panicle initiation } & \multicolumn{2}{|c|}{ Flowering } & \multicolumn{2}{|c|}{ Harvesting } \\
\hline & $2009-10$ & $2010-11$ & $2009-10$ & $2010-11$ & $2009-10$ & $2010-11$ & $2009-10$ & $2010-11$ \\
\hline \multicolumn{9}{|c|}{ Crop establishment and weed management methods } \\
\hline $\mathrm{M}_{1}: \mathrm{DPS}$ & 219.5 & 205.5 & 381.7 & 348.7 & 355.7 & 322.9 & 296.3 & 295.0 \\
\hline $\mathrm{M}_{2}: \mathrm{DPS}+$ Almix & 223.4 & 211.1 & 397.7 & 356.8 & 373.9 & 341.7 & 307.3 & 314.4 \\
\hline $\begin{array}{l}\mathrm{M}_{3} \text { :DPS without thinning and hand } \\
\text { weeding in the intersect }+ \text { Almix }\end{array}$ & 257.7 & 241.5 & 326.5 & 314.5 & 288.5 & 286.3 & 249.9 & 253.8 \\
\hline $\mathrm{M}_{4}$ :Drum seeding & 239.0 & 228.1 & 373.4 & 334.1 & 343.3 & 316.2 & 289.7 & 265.9 \\
\hline $\mathrm{SEm} \pm$ & 7.5 & 5.6 & 13.9 & 8.8 & 12.5 & 10.5 & 11.2 & 9.0 \\
\hline $\mathrm{CD}(\mathrm{P}=0.05)$ & 18.4 & 13.7 & 34.1 & 21.5 & 30.7 & 25.6 & 27.3 & 22.1 \\
\hline \multicolumn{9}{|l|}{ Nutrient management practices } \\
\hline $\mathrm{S}_{1}$ :Absolute control & 202.9 & 186.2 & 315.1 & 290.1 & 284.8 & 277.6 & 250.2 & 252.1 \\
\hline $\mathrm{S}_{2}: \mathrm{RDF}+\mathrm{FYM}$ & 235.2 & 222.9 & 368.0 & 340.4 & 337.4 & 313.7 & 285.4 & 279.1 \\
\hline $\mathrm{S}_{3}: \mathrm{S}_{2}+$ Pseudomonas & 249.1 & 234.9 & 394.5 & 356.8 & 364.8 & 332.2 & 299.1 & 296.7 \\
\hline $\mathrm{S}_{4}: \mathrm{S}_{2}+$ Azophosmet $+\mathrm{PPFM}$ & 252.4 & 242.1 & 401.7 & 366.9 & 374.4 & 343.6 & 308.6 & 301.2 \\
\hline $\mathrm{SEm} \pm$ & 5.4 & 5.0 & 9.0 & 7.0 & 8.5 & 7.8 & 6.3 & 7.2 \\
\hline $\mathrm{CD}(\mathrm{P}=0.05)$ & 11.2 & 10.4 & 18.5 & 14.5 & 17.5 & 16.0 & 13.0 & 14.8 \\
\hline \multicolumn{9}{|l|}{ Interaction $(\mathrm{MxS})$} \\
\hline $\mathrm{SEm} \pm$ & 12.0 & 10.4 & 20.9 & 15.0 & 19.3 & 17.0 & 15.6 & 15.4 \\
\hline $\mathrm{CD}(\mathrm{P}=0.05)$ & 26.6 & 22.6 & 46.7 & 33.0 & 42.9 & 37.6 & 35.3 & 33.7 \\
\hline
\end{tabular}


Int.J.Curr.Microbiol.App.Sci (2017) 6(11): 3725-3737

Table.3 Effect of establishment, weed and nutrient management practices on dry matter production $\left(\mathrm{g} \mathrm{m}^{-2}\right)$ at different growth stages of rice

\begin{tabular}{|c|c|c|c|c|c|c|c|c|}
\hline \multirow{2}{*}{ Treatments } & \multicolumn{2}{|c|}{ Active tillering } & \multicolumn{2}{|c|}{ Panicle initiation } & \multicolumn{2}{|c|}{ Flowering } & \multicolumn{2}{|c|}{ Harvesting } \\
\hline & $2009-10$ & $2010-11$ & $2009-10$ & $2010-11$ & $2009-10$ & $2010-11$ & $2009-10$ & 2010-11 \\
\hline \multicolumn{9}{|c|}{ Crop establishment and weed management methods } \\
\hline $\mathrm{M}_{1}: \mathrm{DPS}$ & 128.8 & 127.1 & 372.4 & 339.7 & 727.2 & 658.4 & 921.1 & 892.6 \\
\hline $\mathrm{M}_{2}: \mathrm{DPS}+\mathrm{Almix}$ & 133.7 & 129.7 & 393.2 & 363.0 & 752.8 & 698.8 & 975.5 & 923.4 \\
\hline $\begin{array}{l}\mathrm{M}_{3} \text { :DPS without thinning and hand } \\
\text { weeding in the intersect + Almix }\end{array}$ & 140.8 & 137.5 & 278.1 & 282.9 & 570.4 & 563.9 & 781.1 & 733.2 \\
\hline $\mathrm{M}_{4}$ :Drum seeding & 113.2 & 115.3 & 300.7 & 303.7 & 580.8 & 596.0 & 793.6 & 814.2 \\
\hline SEm \pm & 7.1 & 3.7 & 9.7 & 12.0 & 14.8 & 18.8 & 25.8 & 27.4 \\
\hline $\mathrm{CD}(\mathrm{P}=0.05)$ & 17.5 & 9.1 & 23.7 & 29.5 & 36.3 & 46.0 & 63.2 & 67.1 \\
\hline \multicolumn{9}{|l|}{ Nutrient management practices } \\
\hline $\mathrm{S}_{1}$ :Absolute control & 105.3 & 95.5 & 262.9 & 237.5 & 546.0 & 487.5 & 764.8 & 678.3 \\
\hline $\mathrm{S}_{2}: \mathrm{RDF}+\mathrm{FYM}$ & 131.9 & 131.4 & 345.2 & 336.5 & 662.6 & 650.4 & 868.7 & 863.3 \\
\hline $\mathrm{S}_{3}: \mathrm{S}_{2}+$ Pseudomonas & 138.2 & 140.4 & 365.9 & 354.5 & 705.4 & 679.3 & 911.9 & 898.9 \\
\hline $\mathrm{S}_{4}: \mathrm{S}_{2}+$ Azophosmet $+\mathrm{PPFM}$ & 141.1 & 142.2 & 370.5 & 360.8 & 717.4 & 699.8 & 926.0 & 922.9 \\
\hline SEm \pm & 2.4 & 2.8 & 7.8 & 8.0 & 14.6 & 13.5 & 20.0 & 15.6 \\
\hline $\mathrm{CD}(\mathrm{P}=0.05)$ & 5.0 & 5.8 & 16.0 & 16.5 & 30.1 & 27.9 & 41.3 & 32.3 \\
\hline \multicolumn{9}{|l|}{ Interaction $(\mathrm{MxS})$} \\
\hline SEm \pm & 8.3 & 6.2 & 16.6 & 18.4 & 29.3 & 30.0 & 43.2 & 38.6 \\
\hline $\mathrm{CD}(\mathrm{P}=0.05)$ & 19.4 & 13.6 & 36.4 & 40.9 & 63.3 & 66.5 & 95.1 & 87.0 \\
\hline
\end{tabular}


Table.4 Effect of establishment, weed and nutrient management practices on leaf area index at different growth stages and days to 50 per cent panicle emergence of rice

\begin{tabular}{|c|c|c|c|c|c|c|c|c|}
\hline \multirow{3}{*}{ Treatments } & \multicolumn{6}{|c|}{ Leaf area index } & \multirow{2}{*}{\multicolumn{2}{|c|}{$\begin{array}{l}\text { Days to } 50 \text { per cent } \\
\text { panicle emergence }\end{array}$}} \\
\hline & \multicolumn{2}{|c|}{ Active tillering } & \multicolumn{2}{|c|}{ Panicle initiation } & \multicolumn{2}{|c|}{ Flowering } & & \\
\hline & $2009-10$ & $2010-11$ & $2009-10$ & $2010-11$ & $2009-10$ & $2010-11$ & $2009-10$ & $2010-11$ \\
\hline \multicolumn{9}{|c|}{ Crop establishment and weed management methods $(M)$} \\
\hline $\mathrm{M}_{1}: \mathrm{DPS}$ & 1.46 & 1.37 & 4.10 & 3.73 & 4.61 & 4.19 & 99.3 & 98.9 \\
\hline $\mathrm{M}_{2}: \mathrm{DPS}+\mathrm{Almix}$ & 1.54 & 1.47 & 4.23 & 3.87 & 4.82 & 4.42 & 99.3 & 98.6 \\
\hline $\begin{array}{l}\mathrm{M}_{3} \text { :DPS without thinning and hand } \\
\text { weeding in the intersect + Almix }\end{array}$ & 1.62 & 1.54 & 3.58 & 3.44 & 3.87 & 3.80 & 98.8 & 97.7 \\
\hline $\mathrm{M}_{4}$ :Drum seeding & 1.21 & 1.16 & 3.28 & 2.88 & 3.97 & 3.62 & 97.3 & 96.5 \\
\hline $\mathrm{SEm} \pm$ & 0.05 & 0.04 & 0.14 & 0.10 & 0.16 & 0.14 & 0.6 & 0.6 \\
\hline $\mathrm{CD}(\mathrm{P}=0.05)$ & 0.13 & 0.09 & 0.35 & 0.24 & 0.40 & 0.34 & 1.4 & 1.5 \\
\hline \multicolumn{9}{|l|}{ Nutrient management practices $(S)$} \\
\hline $\mathrm{S}_{1}$ :Absolute control & 1.13 & 1.03 & 2.79 & 2.57 & 3.18 & 3.04 & 97.5 & 97.0 \\
\hline $\mathrm{S}_{2}: \mathrm{RDF}+\mathrm{FYM}$ & 1.46 & 1.38 & 3.81 & 3.50 & 4.47 & 4.16 & 99.8 & 98.7 \\
\hline $\mathrm{S}_{3}: \mathrm{S}_{2}+$ Pseudomonas & 1.60 & 1.53 & 4.23 & 3.87 & 4.72 & 4.31 & 98.8 & 98.1 \\
\hline $\mathrm{S}_{4}: \mathrm{S}_{2}+$ Azophosmet $+\mathrm{PPFM}$ & 1.65 & 1.59 & 4.37 & 3.99 & 4.90 & 4.50 & 98.8 & 97.9 \\
\hline $\mathrm{SEm} \pm$ & 0.03 & 0.03 & 0.09 & 0.07 & 0.11 & 0.10 & 0.5 & 0.5 \\
\hline $\mathrm{CD}(\mathrm{P}=0.05)$ & 0.07 & 0.06 & 0.18 & 0.15 & 0.22 & 0.20 & 1.0 & 0.9 \\
\hline \multicolumn{9}{|l|}{ Interaction $(\mathrm{MxS})$} \\
\hline $\mathrm{SEm} \pm$ & 0.08 & 0.06 & 0.21 & 0.16 & 0.25 & 0.22 & 1.0 & 1.0 \\
\hline $\mathrm{CD}(\mathrm{P}=0.05)$ & 0.17 & 0.14 & 0.47 & 0.35 & 0.55 & 0.48 & NS & NS \\
\hline
\end{tabular}


Int.J.Curr.Microbiol.App.Sci (2017) 6(11): 3725-3737

Table.5 Effect of establishment, weed and nutrient management practices on yield attributes of rice

\begin{tabular}{|c|c|c|c|c|c|c|c|c|c|c|}
\hline \multirow{2}{*}{ Treatments } & \multicolumn{2}{|c|}{ Panicles $\mathrm{m}^{-2}$} & \multicolumn{2}{|c|}{ Panicle weight (g) } & \multicolumn{2}{|c|}{ Test weight (g) } & \multicolumn{2}{|c|}{ Filled grains panicle ${ }^{-1}$} & \multicolumn{2}{|c|}{ Filled grain percentage } \\
\hline & $2009-10$ & $2010-11$ & $2009-10$ & $2010-11$ & $2009-10$ & $2010-11$ & $2009-10$ & $2010-11$ & $2009-10$ & $2010-11$ \\
\hline \multicolumn{11}{|c|}{ Crop establishment and weed management methods } \\
\hline $\mathrm{M}_{1}: \mathrm{DPS}$ & 264.9 & 269.7 & 4.30 & 3.83 & 20.24 & 19.73 & 200.8 & 189.0 & 85.7 & 83.4 \\
\hline $\mathrm{M}_{2}: \mathrm{DPS}+$ Almix & 275.4 & 274.5 & 4.40 & 4.00 & 19.89 & 19.94 & 204.2 & 193.7 & 86.4 & 84.7 \\
\hline \multicolumn{11}{|l|}{$\mathrm{M}_{3}$ :DPS without thinning and } \\
\hline hand weeding in the intersect + & 235.3 & 228.2 & 4.10 & 3.65 & 19.86 & 19.90 & 184.9 & 179.2 & 83.7 & 83.6 \\
\hline \multicolumn{11}{|l|}{ Almix } \\
\hline $\mathrm{M}_{4}$ :Drum seeding & 243.8 & 246.9 & 3.94 & 3.41 & 19.68 & 19.82 & 172.7 & 168.9 & 82.3 & 82.8 \\
\hline $\mathrm{SEm} \pm$ & 6.5 & 9.2 & 0.11 & 0.09 & 0.22 & 0.28 & 6.4 & 4.9 & 0.5 & 0.4 \\
\hline $\mathrm{CD}(\mathrm{P}=0.05)$ & 16.0 & 22.4 & 0.26 & 0.23 & NS & NS & 15.6 & 12.1 & 1.1 & 1.1 \\
\hline \multicolumn{11}{|l|}{ Nutrient management practices } \\
\hline $\mathrm{S}_{1}$ :Absolute control & 224.2 & 219.6 & 3.79 & 3.44 & 19.81 & 19.64 & 175.5 & 171.0 & 82.5 & 82.3 \\
\hline $\mathrm{S}_{2}: \mathrm{RDF}+\mathrm{FYM}$ & 255.2 & 256.4 & 4.09 & 3.74 & 19.90 & 19.80 & 188.0 & 180.8 & 84.5 & 83.1 \\
\hline $\mathrm{S}_{3}: \mathrm{S}_{2}+$ Pseudomonas & 267.3 & 270.8 & 4.39 & 3.81 & 19.95 & 19.93 & 197.3 & 188.0 & 85.3 & 84.4 \\
\hline $\mathrm{S}_{4}: \mathrm{S}_{2}+$ Azophosmet $+\mathrm{PPFM}$ & 272.7 & 272.6 & 4.47 & 3.90 & 20.00 & 20.03 & 201.7 & 191.1 & 85.7 & 84.8 \\
\hline $\mathrm{SEm} \pm$ & 5.2 & 5.2 & 0.06 & 0.07 & 0.14 & 0.22 & 2.6 & 3.2 & 0.3 & 0.3 \\
\hline $\mathrm{CD}(\mathrm{P}=0.05)$ & 10.8 & 10.8 & 0.12 & 0.14 & NS & NS & 5.3 & 6.5 & 0.7 & 0.5 \\
\hline \multicolumn{11}{|l|}{ Interaction (MxS) } \\
\hline $\mathrm{SEm} \pm$ & 11.2 & 12.9 & 0.15 & 0.15 & 0.33 & 0.47 & 7.8 & 7.4 & 0.7 & 0.6 \\
\hline $\mathrm{CD}(\mathrm{P}=0.05)$ & 24.5 & 29.1 & 0.34 & 0.33 & NS & NS & 18.0 & 16.5 & 1.6 & 1.4 \\
\hline
\end{tabular}


Int.J.Curr.Microbiol.App.Sci (2017) 6(11): 3725-3737

Table.6 Effect of establishment, weed and nutrient management practices on yield $\left(\mathrm{t} \mathrm{ha}^{-1}\right)$ and harvest index $(\%)$ of rice

\begin{tabular}{|c|c|c|c|c|c|c|}
\hline \multirow{2}{*}{ Treatments } & \multicolumn{2}{|c|}{ Grain yield $\left(\mathrm{t} \mathrm{ha}^{-1}\right)$} & \multicolumn{2}{|c|}{ Straw yield $\left(\mathrm{t} \mathrm{ha}^{-1}\right)$} & \multicolumn{2}{|c|}{ Harvest index (\%) } \\
\hline & $2009-10$ & $2010-11$ & $2009-10$ & $2010-11$ & $2009-10$ & $2010-11$ \\
\hline \multicolumn{7}{|c|}{ Crop establishment and weed management methods } \\
\hline $\mathrm{M}_{1}: \mathrm{DPS}$ & 5.50 & 5.28 & 7.13 & 7.15 & 43.45 & 42.37 \\
\hline $\mathrm{M}_{2}: \mathrm{DPS}+\mathrm{Almix}$ & 5.82 & 5.51 & 7.38 & 7.33 & 44.05 & 42.89 \\
\hline $\begin{array}{l}\mathrm{M}_{3} \text { :DPS without thinning and hand } \\
\text { weeding in the intersect + Almix }\end{array}$ & 4.28 & 4.06 & 6.43 & 6.77 & 39.96 & 37.44 \\
\hline $\mathrm{M}_{4}$ :Drum seeding & 4.66 & 4.21 & 7.40 & 7.69 & 38.66 & 35.43 \\
\hline SEm \pm & 0.23 & 0.16 & 0.24 & 0.20 & 0.60 & 0.40 \\
\hline $\mathrm{CD}(\mathrm{P}=0.05)$ & 0.56 & 0.38 & 0.58 & 0.50 & 1.47 & 0.99 \\
\hline \multicolumn{7}{|l|}{ Nutrient management practices } \\
\hline$S_{1}$ :Absolute control & 3.83 & 3.79 & 5.41 & 5.82 & 41.36 & 39.29 \\
\hline $\mathrm{S}_{2}: \mathrm{RDF}+\mathrm{FYM}$ & 5.23 & 4.92 & 7.61 & 7.67 & 40.61 & 38.99 \\
\hline $\mathrm{S}_{3}: \mathrm{S}_{2}+$ Pseudomonas & 5.55 & 5.15 & 7.63 & 7.69 & 41.94 & 39.90 \\
\hline $\mathrm{S}_{4}: \mathrm{S}_{2}+$ Azophosmet $+\mathrm{PPFM}$ & 5.65 & 5.19 & 7.69 & 7.75 & 42.21 & 39.94 \\
\hline SEm \pm & 0.09 & 0.09 & 0.11 & 0.11 & 0.43 & 0.36 \\
\hline $\mathrm{CD}(\mathrm{P}=0.05)$ & 0.19 & 0.18 & 0.24 & 0.23 & 0.89 & 0.74 \\
\hline \multicolumn{7}{|l|}{ Interaction (MxS) } \\
\hline $\mathrm{SEm} \pm$ & 0.28 & 0.22 & 0.31 & 0.28 & 0.96 & 0.74 \\
\hline $\mathrm{CD}(\mathrm{P}=0.05)$ & 0.65 & 0.49 & NS & NS & NS & NS \\
\hline
\end{tabular}


The improved yield attributes might be ascribed to reduce above and below ground competition, greater root and shoot development, enhanced solar radiation interception and nutrients uptake. This result is in conformity with the finding of Sridevi and Chellamuthu (2007).

Combined application of RDF + FYM + Azophosmet + PPFM gave higher yield attributes during both the years. But it was at par with of RDF + FYM + Pseudomonas. The superior yield attributes in biofertilizers applied treatments might be attributable to higher occurrence of beneficial microbes, greater and balanced nutrient availability throughout the crop growth. This result is in confirmation with the findings of Kalaiyarasi (2009).

\section{Grain yield}

Crop establishment methods, weed management and nutrient management practices exerted a profound impact on grain yield $\left(\mathrm{t} \mathrm{ha}^{-1}\right)$ of rice during both the years of experimentation (Table 6). Direct planting system (DPS) + EPOE of almix @ $4 \mathrm{~g}$ a.i. ha ${ }^{-1}$ recorded perceptibly more grain yield during both the years. However, comparable grain yield was noticed in direct planting system. DPS + EPOE of almix @ $4 \mathrm{~g}$ a.i. ha ${ }^{-1}$ resulted in 35.9 and 35.6 per cent higher grain yield than DPS without thinning and hand weeding in intersect + EPOE of almix @ $4 \mathrm{~g}$ a.i. ha ${ }^{-1}$ during rabi, 2009-10 and 2010-11, respectively which might be due to less intra plant competition and weed infestation, larger root system along with greater crop canopy, higher nutrient uptake and improved yield attributes. The DPS without thinning and hand weeding in the intersect + EPOE of almix @ $4 \mathrm{~g}$ a.i ha ${ }^{-1}$ registered less yield due to higher intra plant competition and greater grass weed infestation. This is in line with the findings of Kumar et al., (2010a) who reported that almix @4 g a.i. ha ${ }^{-1}$ at 20 DAT was more effective against broad leaved weeds and very little to sedges and failed to control major grassy weeds which resulted in lower grain yield. Puniya et al., (2007a) stated that among the different weed species, grassy weeds pose greater competition.

Combined application of RDF + FYM + Azophosmet + PPFM registered more grain yield during both the years and the percentage increase in grain yield was 47.5 and 37 per cent over absolute control during rabi, 200910 and 2010-11, respectively which might be attributed to increased nutrient availability throughout the crop growth which resulted in improved yield attributes. This finding is in accordance with the results of Virdia and Mehta (2010). However, comparable grain yield was observed with combined of RDF + FYM + Pseudomonas.

\section{Straw yield}

Crop establishment methods, weed management and nutrient management practices significantly altered the straw yield $\left(\mathrm{t} \mathrm{ha}^{-1}\right)$ of rice during both the years (Table 6). Drum seeding registered perceptibly more straw yield during both the years. However, comparable straw yield was obtained with Direct planting system (DPS) + EPOE of almix @ $4 \mathrm{~g}$ a.i. ha ${ }^{-1}$ and DPS during rabi 2009-10 and only with Direct planting system (DPS) + EPOE of almix @ $4 \mathrm{~g}$ a.i. ha ${ }^{-1}$ during rabi 2010-11. Higher straw yield in drum seeding was due to less remobilization of photosynthates to grain. This is contradicting to the finding of Reddy (2010).

Combined application of RDF + FYM + Azophosmet + PPFM significantly recorded greater straw yield during both the years. However, all the nutrient applied plots produced comparable straw yield over absolute control which might be due to more 
tillers and higher DMP which is facilitated by greater nutrient availability. This result is in accordance with the findings of Kalaiyarasi (2009).

\section{Harvest index}

The harvest index (\%) of rice was significantly influenced by the crop establishment, weed management and nutrient management practices during both the years (Table 6). Direct planting system + EPOE of almix @ $4 \mathrm{~g}$ a.i. ha ${ }^{-1}$ resulted in higher harvest index during both the years.

However, comparable harvest index was obtained with DPS might have attributed to better soil aeration provided by rotary weeding and better translocation of photosynthates from vegetative parts to grains. Perceptibly, higher harvest index was registered with application of $\mathrm{RDF}+\mathrm{FYM}+$ Azophosmet + PPFM during both the years. However, comparable harvest index was observed with RDF + FYM + Pseudomonas application and absolute control. This was owing to the efficient translocation of food assimilates by biofertilizers. This result is in conformity with the findings of Kalaiyarasi (2009).

The results of the present investigation clearly indicated that direct planting system (DPS) + EPOE of almix @ $4 \mathrm{~g}$ a.i. ha ${ }^{-1}$ in association with combined application of recommended dose of fertilizer (150:50:50 kg NPK ha $\left.{ }^{-1}\right)+$ $12.5 \mathrm{t} \mathrm{ha}^{-1}$ farm yard manure + biofertilizers viz., Azophosmet as soil application @ $2 \mathrm{~kg}$ $\mathrm{ha}^{-1}$ and seed treatment @2.5 $\mathrm{g} \mathrm{kg}^{-1}$ and 0.1 per cent Pink pigmented facultative methylotrophs (PPFM) as foliar spray at active tillering, panicle initiation and at 50 per cent flowering stage recorded improved growth, yield attributes and productivity of medium duration rice variety $\mathrm{CO}$ (R) 50 under direct seeded condition during rabi season.

\section{References}

Barik, A.K., Das, A., Giri, A.K. and Chattopadhyay, G.N. 2006. Effect of integrated plant nutrient management on growth, yield and production economics of wet season rice (Oryza sativa). Indian Journal of Agric. Sci. 76(11):657-60.

Baskar, P. 2009. Standardisaton of nursery techniques and crop geometry for rice under system of rice intensification (SRI). M.Sc. (Ag.) Thesis. Tamil Nadu Agricultural University, Coimbatore, Tamil Nadu, India.

Gangwar, K.S., Gill, M.S., Tomar, O.K. and Pandey, D.K. 2008. Effect of crop establishment methods on growth, productivity and soil fertility of rice (Oryza sativa) based cropping systems. Indian J. Agron. 53: 102-106.

Gomez, K.A. and Gomez, A.A. 2010. Statistical procedures for agricultural research. ( $2^{\text {nd }}$ Ed.). Wiley India Pvt Ltd., India.

Janarthanan, P. 2008. Impact of number of seedlings and spacing in Direct Planting System and modified SRI method in rice cultivation. M. Sc. (Ag.) Thesis. Tamil Nadu Agricultural University, Coimbatore, Tamil Nadu, India.

Jayasankar, R. and Thyagarajan, S. 2010. Constraints experienced by the rice farmers in adopting recommended biofertilizer practices. International Journal of Current Research 7: 18-20.

Kalaiyarasi, D. 2009. Studies on stand establishment techniques and nutrient management practices in wet seeded lowland rice. M.Sc. (Ag) Thesis. Tamil $\mathrm{Nadu}$ Agricultural University, Coimbatore.

Kumar, J., Kumar, A. and Sharma, B.C. 2010a. Effect of chemical and crop establishment methods on weeds and yield of rice and their residual effects on 
succeeding wheat crop. Indian J. Weed Sci. 42: 78-82.

Mirza, H., Ali, M.H., Alam, M.M., Akther, M. and Alam, K.F. (2009). Evaluation of pre-emergence herbicide and hand weeding on the weed control efficiency and performance of transplanted Aus rice. American-Eurasian Journal of Agronomy 2: 138-143.

Puniya, R., Pandey, P.C. and Bisht, P.S. 2007a. Performance of Trisulfuron, Trisulfuron + Pretilachlor and Bensulfuron-methyl in transplanted rice (Oryza sativa L.). Indian J. Weed Sci. 39:120-122.

Ramasamy, S., Susheela, C. and Sathyamoorthy K. 2006. Direct planting system - Energy saving high output rice establishment technique for lowland. $\mathrm{p}$. 494. In Abstract, Second International Rice Congress, New Delhi, India, 9-13 Oct. 2006.

Rao, C.P. and Raju, M.S. 1987. Effect of age of seedlings nitrogen and spacing on rice. Indian J. Agron. 32(1):100-102.

Reddy, G.S. 2010. Integrated weed management in drum seeding and direct planting system. M.Sc. (Ag.) Thesis. Tamil Nadu Agricultural University, Coimbatore, Tamil Nadu, India.

Shrirame, M.D., Rajgire, H.J. and Rajgire, A.H. 2000. Effect of spacing and seedling number per hill on growth attributes and yield of rice hybrids under lowland condition. J. Soils and
Crops 10(1):109-113.

Singh, M. and Singh, R.P. 2010. Influence of crop establishment methods and weed management practices on yield and economics of direct-seeded rice (Oryza sativa). Indian J. Agron. 55:224-229.

Sridevi, V. and Chellamuthu, V. 2007. Effect of System of Rice Intensification (SRI) practices on the yield and yield attributes of rice. p. 74. In Papers and extended summaries of $2^{\text {nd }}$ National symposium on System of Rice Intensification in India-progress and prospects, Agartala, India. 3-5 Oct. 2007.

Viera, R.M. and Alvarez, B.D. 2006. Practical applications of bacterial biofertilizers and biostimulators. p. 467-477. In Uphoff, N., A.S. Ball, E. Fernandes, H. Herren, O. Husson, M. Lang, C. Palm, J. Pretty, P. Sanchez, N. Sanginga and J. Thies. (eds.). Biological approaches to sustainable soil systems. CRC press/Taylor and Francis group, Florida, United States of America.

Virdia, H.M. and Mehta, H.D. 2010. Integrated Nutrient Management in transplanted rice (Oryza sativa L.). International Journal of Agric. Sci. 6: 295-299.

Yoshida, S., Forno, D.A., Cock, J.H. and Gomez, K.A. 1976. Laboratory manual for physiological studies of rice. International Rice Research Institute, Philippines.

\section{How to cite this article:}

Sridevi, V., S. Jeyaraman, S. Ramasamy and Chinnusamy, C. 2017. Influence of Crop Establishment Methods, Weed and Nutrient Management Practices on Growth and Yield of Direct Seeded Rice (Oryza sativa). Int.J.Curr.Microbiol.App.Sci. 6(11): 3725-3737. doi: https://doi.org/10.20546/ijcmas.2017.611.436 